\title{
Accumulation of organochlorines and mercury in flounder - an approach to pollution assessments
}

\author{
A. Köhler ${ }^{1}$, U. Harms ${ }^{2}, \&$ B. Luckas ${ }^{3}$ \\ ${ }^{1}$ Biologische Anstalt Helgoland (Zentrale); Notkestraße 31, D-2000 Hamburg 52, FRG \\ ${ }^{2}$ Bundesforschungsanstalt für Fischerei, Labor für Radioökologie der Gewässer; \\ Wüstland 2, D-2000 Hamburg 55, FRG \\ ${ }^{3}$ Städtisches Untersuchungsamt Flensburg; D-2390 Flensburg, FRG
}

\begin{abstract}
Levels of PCBs, HCB and Hg were determined in the muscle tissue of flounder (Platichthys flesus L.), sampled at two sites of the highly industrialized Elbe estuary which is characterized by a decreasing gradient of contaminant levels in water and sediments towards the mouth of the river. The contaminant levels were compared to those found in muscle tissue of flounders caught in an unpolluted reference area, the Eider estuary. Juvenile flounders $(1-2 \mathrm{~cm}$ total length) caught during their migration from the southern North Sea coast into the Elbe estuary in early summer showed a significantly higher level of contamination at both Elbe stations than those from the reference area. In the following spring, the flounders, having grown to a length of $12-14 \mathrm{~cm}$, reflected the gradient of contaminants measured in water and sediment. However, during summer and late autumn a drastic increase in average contaminant concentration was observed in the muscle tissue of flounders taken from the less polluted estuarine site. It became evident that severe oxygen depletion in the heavily polluted area near Hamburg had provoked the migration of highly contaminated fish downstream to the less polluted sampling area; thus intermingling with the less contaminated flounder population of this region had occurred. The results obtained indicate that careful analysis of environmentally controlled behavioural patterns in the species used for monitoring purposes as well as an appropriate statistical treatment of the data gained from chemical analysis are essential for assessing the contaminant concentrations in organisms in relation to the pollution load of their habitats.
\end{abstract}

\section{INTRODUCTION}

Contamination of the aquatic environment with potentially harmful substances with its subsequent impact on organisms is most dramatic in estuaries and adjacent semienclosed marginal seas in the vicinity of highly populated and industrialized regions. The aim of the present study was to compare contaminant levels in fish species from the Elbe estuary with those from the Eider, and to investigate whether pronounced, different contaminant levels in the habitats are reflected by corresponding differences in the contaminant levels of the bio-indicators selected for this study.

The mouth of the Elbe river is a coastal plain estuary. The river drains highly industrialized countries, such as Czechoslovakia and the German Democratic Republic. In addition, the lower tidal part is largely influenced by the input of contaminants from the city of Hamburg and from industrial regions located downstream.

In comparison with the Elbe, the river Eider with similar hydrological conditions is 
only insignificantly influenced by anthropogenic activities. This river, draining mainly agricultural areas, is subjected only to minor stress from industrial and municipal effluents for the whole length of its course.

In the present study interest was focussed on mercury $(\mathrm{Hg})$, hexachlorobenzene (HCB) and polychlorinated biphenyls (PCBs) which were regarded as representative indicator substances for the areas under study; this is especially relevant for the Elbe river, where these substances play a dominant role in industrial discharges (ARGE Elbe, 1980, 1982). This paper is part of a study, carried out from Spring 1983 to Autumn 1984, on histological and electron-microscopical investigations of the teleost liver with respect to sublethal effects of contaminants in selected fish species.

\section{MATERIAL AND METHODS}

The flounder (Platichthys flesus L.), a catadromous and euryhaline species, which is wide-spread in coastal and estuarine regions, was selected for the present study. Samples were taken in a region downstream of Hamburg (kilometermark 630-655, Station 1), in an area close to the mouth of the river (kilometermark 670-710, Station 2) and in a reference area close to the mouth of the Eider river (Station 3) (Fig. 1). Samples

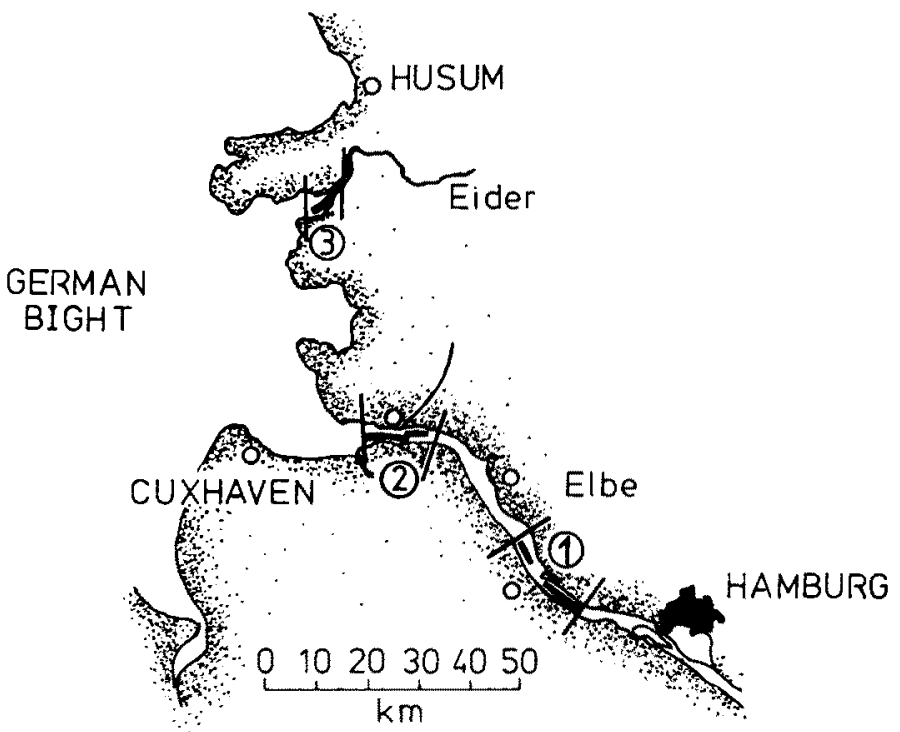

Fig. 1. Sampling sites in the Elbe estuary (Stations 1 and 2) and the reference area in the Eider estuary (Station 3). Cross bars mark the boundaries of sampling sites while solid bars in the river indicate the actual fishing stretch during hauls

of the different age groups of flounder, $\mathrm{O}_{\mathrm{a}}=2-5 \mathrm{~cm}$ total length (time of immigration), $\mathrm{O}_{\mathrm{b}}=7-9 \mathrm{~cm}$ (5 months after immigration), I up to $14 \mathrm{~cm}$, III up to $25 \mathrm{~cm}$, were taken in spring $(\mathrm{A} / \mathrm{M})$, summer $(\mathrm{J} / \mathrm{A})$ and autumn $(\mathrm{O} / \mathrm{N})$ with a dragnet (meshwidth $10 \mathrm{~mm}, 3 \mathrm{~m}$ wide, 30 min dragging time) at the same tide and time of day.

Random subsamples consisted of at least 25 individuals per station, season and age 
group investigated. Altogether, 1067 individuals were analysed for mercury and chlorinated hydrocarbons. Sampling and sample preparation for chemical analysis were carried out according to ICES recommendations (ICES, 1979): Length (below to the nearest $\mathrm{mm}$ ) and weight measurements (to nearest $0.1 \mathrm{~g}$ ) of fish samples were recorded at the time of sampling and whole specimens deep frozen at $-20 \mathrm{C}^{\circ}$, packed in aluminium foil. Samples of muscle tissue were always taken on the right side from the dorso-lateral filet with an acid-resistent stainless steel scalpel in the laboratory. From the older flounders, pieces $(2 \times 2 \mathrm{~cm})$ were cut from the central part of the filet; from individuals of 1-2 cm total length the whole dorsal filet was taken, when the specimens were still partly frozen. For each fish, the condition factor and the liver somatic index were calculated before freezing, based on the data of the eviscerated carcass.

M e r cury was determined in solutions from aliquots of muscle tissue decomposed with nitric acid under pressure (Harms, 1976), followed by cold vapour atomic absorption spectrometry. In order to increase sensitivity and thus enable accurate mercury concentrations to be measured even at extreme low concentrations, mercury vapour was stripped from the sample solution by reduction-aeration and collected by amalgamation on a gold wire.

Following this, the mercury vapour was revolatilized into the cold vapour detector by heating the collector (Harms, 1981).

For determination of the organochlorine compounds selected, the material (muscle tissue) to be analysed was solubilized with a mixture of perchloric and acetic acid followed by isolation of the determinands through liquid-liquid extraction with petrolether. The solvent partition was followed by a sulphuric acid clean-up step (Luckas et al., 1978). The purified extracts were concentrated to a small volume, aliquots of which were subjected to the high-resolution silicafused glass capillary gas chromatography with electron capture detection (Luckas et al., 1978; Schulte \& Malisch, 1983; Specht \& Tillkes, 1980).

Controls to confirm the accuracy of analytical results included intralaboratory tests using certified reference materials, the checking of analytical performance using radiotracers (Harms, 1976), and participation in international and national intercomparison exercises (Berman \& Boyko, 1984; Holden \& Topping, 1981; Thier \& Stijve, 1986).

Statistics : After applying the Barletts test for homogeneity of variances (Sokal \& Rohlf, 1969), all data were treated with nonparametric, distribution-free methods. For the analysis of significant differences between more than two random samples, the Kruskal Wallis test for differences of location in ranked data grouped by single classification was used (Sokal \& Rohlf, 1969). This was necessary for detecting possible differences in the accumulation levels of the compounds inspected between the age groups of flounder, the stations and the seasons investigated. In order to identify the location of differences of contaminant levels, the material was treated with the "post hoc" contrast by a rank sum test of Dunn (Lienert, 1978). In order to check whether the random samples of Station 2 belonged to identical populations, the non-parametric test for goodness of fit of Kolmogoroff \& Smirnov (Sokal \& Rohlf, 1969) was applied. For all tests applied, the differences between the random samples were accepted as significant if the probability of their occurrence by chance was less than $5 \%$. The presentation of the frequency distribution of the data and their graphing on probability paper completed the statistical evaluation. 


\section{RESULTS}

Figure 2 illustrates the concentrations of contaminants in juvenile flounders in relation to catching sites and seasons investigated. Young flounders caught during their immigration into the Elbe estuary in early summer were significantly more highly contaminated with $\mathrm{Hg}, \mathrm{PCBs}$ and $\mathrm{HCB}$ than those caught in the reference area in the Eider estuary.

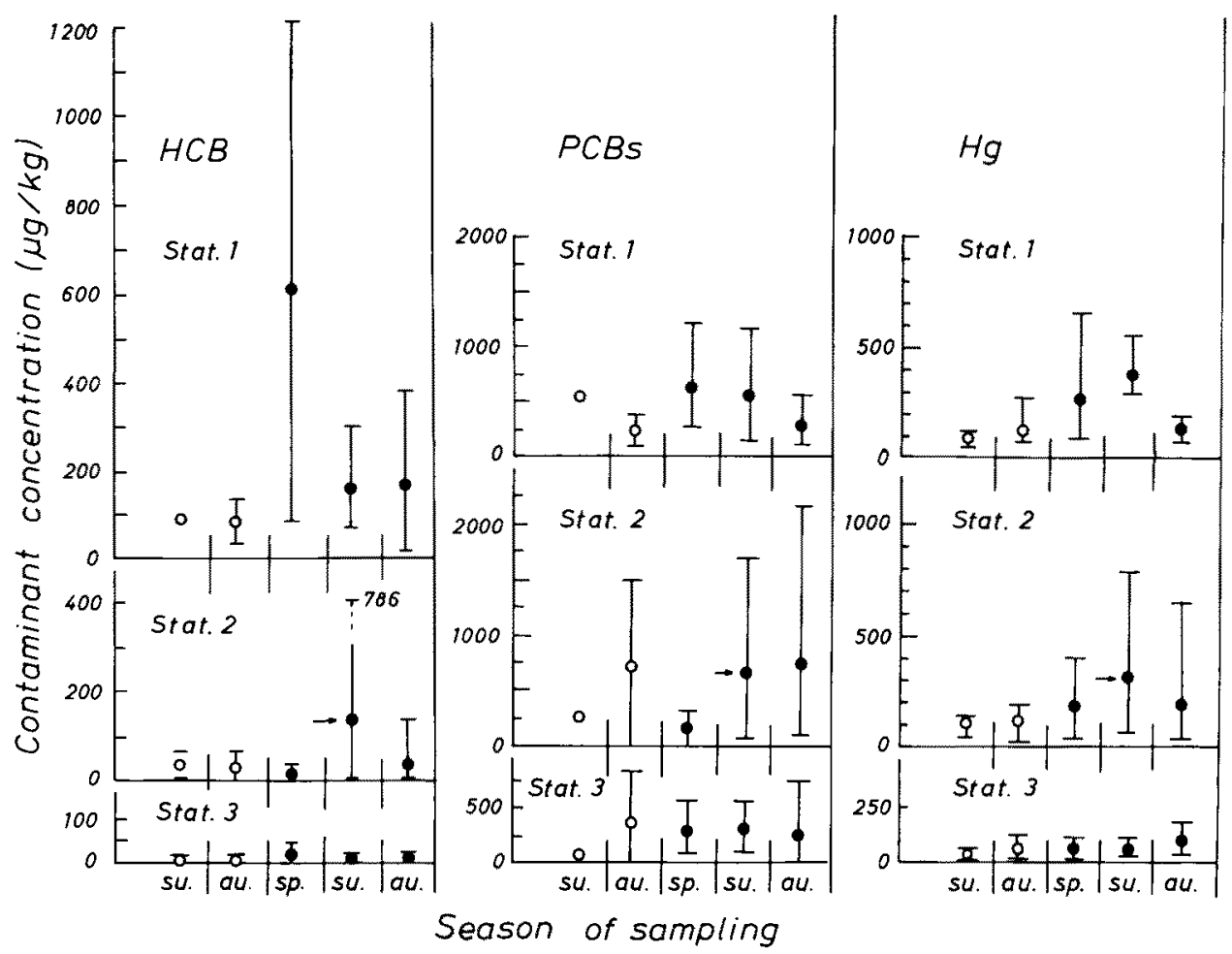

Fig. 2. Seasonal variations of contaminant concentrations in muscle tissue ( $\mu / \mathrm{kg}$ wet weight, arithmetic mean and range) of young flounders. $O=0$-group 1983; $O=1$-group 1984, 0-Group summer 1983, pooled sample. Chlorinated hydrocarbons: $N=340$, mercury: $N=487$. Arrows mark points of significant increase in contaminant levels at Station 2

A clear difference between the two Elbe sampling sites with regard to the contamination levels of the muscle tissue of flounders could not be detected at that time.

However, in the following spring, 1-year old flounders from the region downstream of Hamburg (Station 1) had accumulated significantly more Hg, PCBs and HCB in the filet than flounders of the same age from the catching site near the mouth of the river Elbe (Station 2). The comparison of contaminant levels of 1-year old flounders with those of older individuals 3-4 years of age indicated that a highly significant age-dependent increase of contaminants in muscle tissue occurred at Station 1 (Table 1). At Station 2 and in the reference area (Station 3), additional accumulation in the muscle tissue above the levels measured during the immigration phase were not detected. 
Table 1. Regional differences in the age-contaminant concentration relationship. Comparison of flounder age groups I and III with respect to determinant levels in muscle tissue (arithmetic mean and range in $\mu \mathrm{g} / \mathrm{kg}$ wet weight)

\begin{tabular}{|c|c|c|c|c|c|c|}
\hline \multirow[b]{2}{*}{ Stations } & \multicolumn{2}{|c|}{$\mathrm{HG}$} & \multicolumn{2}{|c|}{$\mathrm{HCB}$} & \multicolumn{2}{|c|}{ PCBs } \\
\hline & I & III & I & III & I & III \\
\hline 1 & $\begin{array}{c}94-654 \\
263 \\
\mathrm{n}=24\end{array}$ & $\begin{array}{c}54-950 \\
\mathbf{4 9 2} \\
\mathrm{n}=26\end{array}$ & $\begin{array}{c}84-1115 \\
618 \\
n=20\end{array}$ & $\begin{array}{c}423-1907 \\
\mathbf{7 5 7} \\
n=27\end{array}$ & $\begin{array}{c}280-1120 \\
635 \\
n=20\end{array}$ & $\begin{array}{c}480-3100 \\
1351 \\
n=27\end{array}$ \\
\hline 2 & $\begin{array}{c}36-403 \\
180 \\
\mathrm{n}=25\end{array}$ & $\begin{array}{c}10-302 \\
144 \\
n=25\end{array}$ & $\begin{array}{c}4-32 \\
17 \\
n=30\end{array}$ & $\begin{array}{c}2-23 \\
8 \\
n=26\end{array}$ & $\begin{array}{c}1-330 \\
170 \\
n=30\end{array}$ & $\begin{array}{c}50-420 \\
172 \\
\mathrm{n}=26\end{array}$ \\
\hline 3 & $\begin{array}{c}18-113 \\
60 \\
n=26\end{array}$ & $\begin{array}{c}30-90 \\
57 \\
n=20\end{array}$ & $\begin{array}{c}2-40 \\
14 \\
n=55\end{array}$ & $\begin{array}{c}1-17 \\
\mathbf{3} \\
\mathbf{n}=20\end{array}$ & $\begin{array}{c}98-539 \\
281 \\
n=55\end{array}$ & $\begin{array}{c}70-240 \\
140 \\
n=20\end{array}$ \\
\hline
\end{tabular}

It is noteworthy that exceptionally high concentrations of HCB were measured in spring downstream of Hamburg at Station 1 in 1-year old individuals. However, a clear decrease in the HCB levels in muscle tissue was observed in summer and late autumn, as shown in Figure 2 for 1-year old flounders. The same seasonal development of HCB concentrations was true for 3-4 year old individuals.

Samples taken near the mouth of the river Elbe (Station 2) revealed a drastic enhancement of the mean concentrations of the contaminants in summer and late

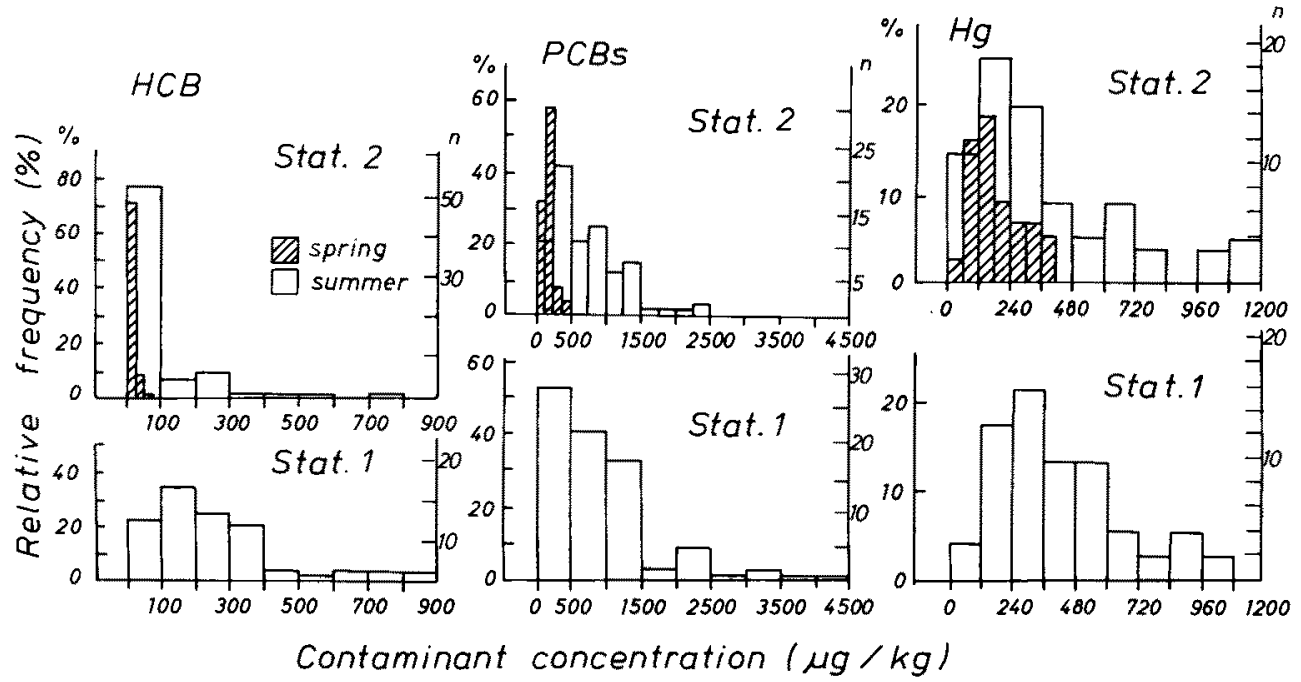

Fig. 3. Frequency distribution of contaminant concentrations in muscle tissue of flounders from Station 1 and 2. Open bars = summer samples of Station 1 and 2 ; hatched bars = spring samples at Station 2 superimposed for comparison. $x$-axis: relative frequency (left) and total number (right) of individuals analysed 
autumn (PCBs $\mathrm{p} \ll 0.001$; HCB $\mathrm{p} \ll 0.001 ; \mathrm{Hg} \mathrm{p}<0.001$ ). As a consequence of these enhancements, statistically significant differences between the Elbe stations in the contaminant accumulation in flounder tissue were not found ( $p \gg 0.10$ for all substances) (Fig. 2).

The graphs showing the frequency distributions of the relevant data (Fig. 3) illustrate the following observations: Contaminant levels of the muscle tissue, as measured in flounders caught at Station 2, varied within low concentration ranges in spring. In summer and late autumn, however, the values of muscle tissue ranged from low contaminant concentrations up to levels three-to tenfold higher than those measured at this station in spring. Furthermore, the distribution of the tissue values proved to be bimodal, as could be affirmed by graphing the data on probability paper, showing that the populations analysed were dimorphic.

A season-related comparison of histograms of both Elbe stations elucidated that the group of higher values in the frequency distributions at Station 2 fitted closely the distribution of continuous variables observed at Station 1 throughout the year.

\section{DISCUSSION}

Recently published relevant literature provides a considerable amount of information on $\mathrm{Hg}$ levels in marine and freshwater fish. Conclusions from the "Six-Year Review of ICES Coordinated Monitoring Programmes" (ICES, 1984), from the results of the current "Joint Monitoring Programme" (1985) and from other relevant publications (Jensen, 1982; Kruse \& Krüger, 1984) indicate that for most species the natural background level is in the region of 0.05 to $0.1 \mathrm{mg} / \mathrm{kg}$, on a wet-weight basis.

During their recent investigations into the occurrence and distribution of contaminants in fish from coastal waters of the North Sea and the Baltic, Luckas \& Harms (in press) recognized that pollution within the German Bight is obviously influenced to a large extent by the inflow of waters from the River Elbe.

Generally, it became clear that the PCBs were the most frequently occurring organochlorine contaminants in fish from the Elbe estuary. The investigations also showed that fish samples from the Elbe on its lower course between the city of Hamburg and near Cuxhaven were severely contaminated with respect to HCB in spring. In the samples taken in summer and autumn at Station 1, there were no individuals with exceptionally high HCB-concentrations in the muscle tissue. With regard to this, the following assumption, based on the literature reviewed by Cairns et al. (1975) and Niimi (1983), can be made: the increasing temperature in summer together with the annually observed severe oxygen depletion in this region potentiate the toxicity of the contaminants. Death of the highly contaminated individuals can be assumed to be caused by the increased uptake of contaminants by hyperventilation, resulting in lethal tissue damage (gills, liver, pancreas). Due to the half life of HCB (approx. 240 days), decrease by elimination or growth is improbable. The results are also in accordance with the data of the ARGE Elbe (1982) on the levels of organochlorines in water and sediments. The data gained confirm that the Elbe obviously contributes to a large extent to the HCBcontamination of the adjacent marine waters of the inner German Bight.

On the basis of the above-mentioned references, the Eider flounders reflected more or less the probably natural background level for mercury, and mildly elevated levels for 
the selected organochlorine compounds, while the significantly elevated level of contaminants measured in muscle of flounders caught in the Elbe estuary at Station 1 indicated an exceptionally high contamination situation. Clearly, habitat-specific differences in the age (size)-contaminant concentration were recognized. Contaminants in flounder muscle tissue increased with the age of the fish from the highly contaminated area (Station 1), whereas in slightly contaminated or uncontaminated waters (Station 2 and 3) no increase with age was found, suggesting that the uptake of contaminants was balanced by growth and/or excretion (Phillips, 1980).

From a more detailed inspection of the Elbe data it became obvious that during certain seasons the flounder is in fact a reliable bio-indicator for the differently contaminated areas within the Elbe estuary. In spring, significant differences in the contaminant levels of muscle tissue between the flounder populations of the two Elbe Stations 1 and 2 could be identified.

The latter reflected decreasing contaminant levels in water and sediments along the tidal section of the Elbe, also measured by other institutions: Investigating the fate and

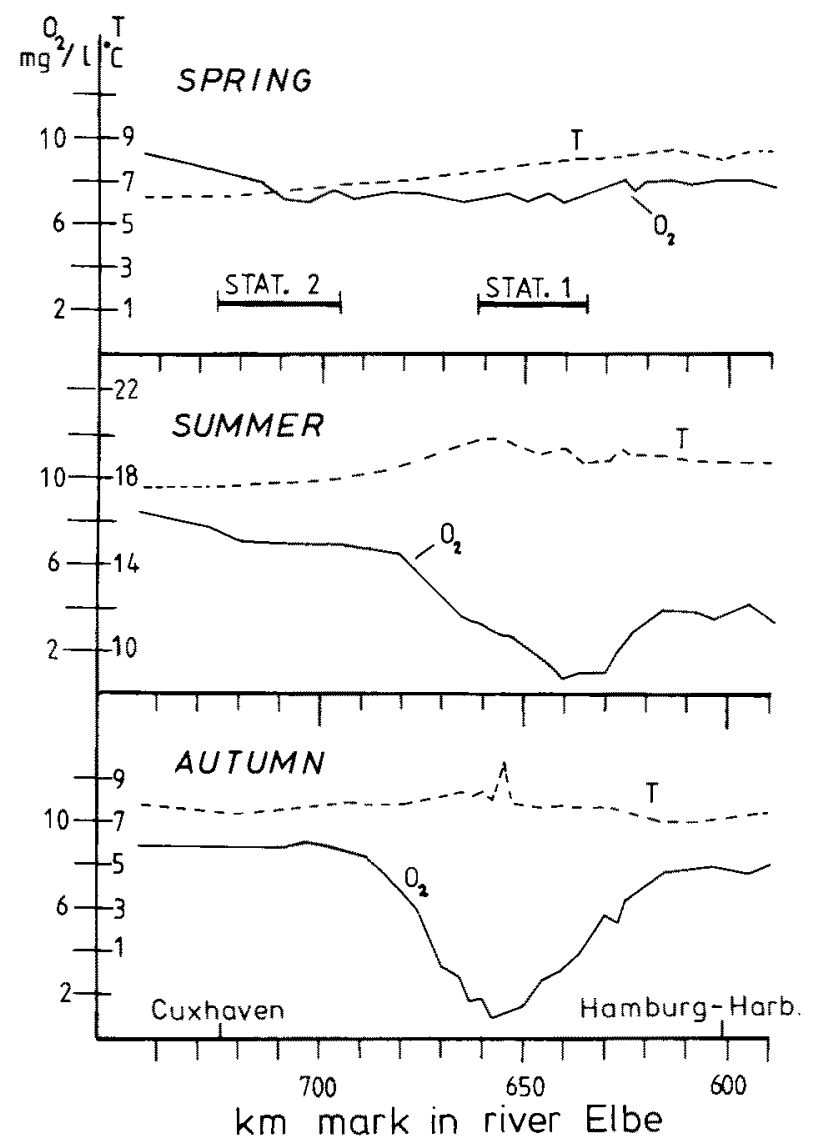

Fig. 4. Oxygen and temperature profiles of the Elbe estuary downstream of Hamburg during the time of investigation (modified after ARGE Elbe, 1983/84) 
distribution of inorganic contaminants (heavy metals) in the lower (tidal) part of the river Elbe; Schmidt et al. (1986) measured total mercury levels (i.e. mercury in the dissolved fraction and adsorbed to the particulate phase) in the water that gave a clear indication of significantly enhanced levels of $500 \mathrm{ng} / \mathrm{l}$ near Hamburg (Station 1) with a decreasing tendency to $70 \mathrm{ng} / \mathrm{l}$ at Station 2 downstream.

The situation in the estuarine system of the River Elbe was also highlighted by sediment investigations performed by the federal working group for "the cleanness of the Elbe river" (ARGE, 1983). The data obtained indicated drastically enhanced mercury concentrations in the $<20 \mu \mathrm{m}$ fraction of sediment with a clear concentration gradient seawards. While the mercury values in the vicinity of Hamburg harbour were about 20 to 30 times higher than the assumed natural background level, the factor decreased downstream to about 6-12 near Cuxhaven and to about 4 in the adjacent area of the inner German Bight.

By using their analytical approach for the determination of lipophilic compounds in water, Gaul \& Ziebarth (1983) found clear evidence of enhanced levels of organic contaminants with a structured distribution along the tidal course of the Elbe (DHI, 1985) just as Schmidt et al. (1986) did for trace elements.

Typically, the concentration of HCB between the inner boundary of the Elbe estuary below Hamburg and its outer front (near Cuxhaven) varied over a range of at least one order of magnitude (from 11.6 to $0.95 \mathrm{ng} / 1$ ), while the corresponding concentrations of PCB congeners decreased by a factor of 2 to 3 (e.g. PCB-180 from 0.59 to $0.22 \mathrm{ng} / \mathrm{l}$ ). Similar results were published previously (ARGE Elbe, 1982).

Thus, it is correct to state - at least on the basis of the spring data obtained during the present study - that the contaminant levels found in the muscle tissue of Elbe flounders reflect the contaminant situation of water and sediment along the lower course of the Elbe estuary. However, the interpretation of the summer and autumn data on the Elbe flounders caught at the two locations revealed severe problems, since factors that potentially interfere with the natural behaviour of the indicator organisms became obvious. A study of the water quality data made clear that the season-dependent (disproportionate) increase in contaminant levels in the fish samples collected at Station 2 coincided with the events of seasonal oxygen deficiency at Station 1 (Fig. 4).

In summer, oxygen levels of $80-90 \%$ were recorded only at the mouth of the Elbe, thus meeting the requirements for the continuous occurrence of fish species typical for this estuarine area, while in the vicinity of Hamburg (Station 1) it dropped to less than $20 \%$ of saturation (ARGE Elbe, 1983). Earlier observations made by Köhler \& Hölzel (1980) and Köhler (1981) demonstrated that periodical depletion of oxygen in the area downstream of Hamburg was responsible for fishkills and migration of flounders towards the mouth of the river. Even though no tagging was carried out, it was obvious that the flounders had migrated to the river mouth, as a drastic increase in the population density was registered there during the periods in question. Comparable avoidance reaction and repopulation was described by Azarovitz et al. (1979) for the summer flounder during repeated oxygen depletions on the US east coast in 1976.

Findings of Dethlefsen \& von Westernhagen (1983) on the effects of oxygen deficiencies in the eastern German Bight support the assumption that certain fish species are able to avoid areas of anoxia by emigration. From the results of the above mentioned authors it can be concluded that the observed seasonal variations in the contaminant 
situation of flounders from Station 2 are closely linked with the migrational behaviour of organisms in relation to deteriorating environmental conditions such as the oxygen depletion at Station 1. Evidently, such "avoidance behaviour" drives severely contaminated fish away from the highly polluted area at Station 1 downstream to the river mouth where they mix with the less contaminated flounder population of Station 2. Seasonal distribution of fish interferes with the assumption that samples taken at various stations always represent the contaminant accumulation pattern at site.

In conclusion, the above reported results demonstrate that external factors affecting the species to be surveilled may restrict their potential as bio-indicators in monitoring. The marked effect of externally induced short-term changes of the habitat conditions can be considered a remarkable source of interpretive errors, especially if analyses are based on sampling only once per year, or on pooled samples. As demonstrated by this analysis, a careful consideration of the possible sources of interfering factors which are important for the populations to be investigated is required before sampling. The present case study reveals that spring is to be recommended as sampling period, since the river and estuarine regions of interest are then sufficiently supplied with oxygen, and migration of flounder is unlikely to occur.

Acknowledgements. We wish to thank Mrs. G. Eicke und Mr. R. Humann for the large amount of technical work on the chemical analysis. For his active advice in the statistical treatment of our data we thank Dr. M. Hoppenheit.

\section{LITERATURE CITED}

ARGE Elbe, 1980. Schwermetalldaten der Elbe. Wassergütestelle Elbe, Hamburg, $66 \mathrm{pp}$.

ARGE Elbe, 1982. Chlorierte Kohlenwasserstoffe - Daten der Elbe. Wassergütestelle Elbe, Hamburg, $107 \mathrm{pp}$.

ARGE Elbe, 1983. Wassergütedaten der Elbe, Wassergütestelle Elbe, Hamburg, $51 \mathrm{pp}$.

Azarovitz, T. R., Byrne, C. J., Silverman, M. J., Freeman, B. L., Smith, W. C., Turner, S. C., Halgren, B. A. \& Festa, P. J., 1979. Effects on fish and lobster. - NOAA prof. Pap. 11, 346-314.

Berman, S. S. \& Boyko, V. J., 1986. Reports on the results of the seventh intercalibration exercise on trace metals in biota (part 1). - Coop. Res. Rep. 138, 1-75.

Cairns, Jv, Heath, A. G. \& Parker, B. C., 1975. The effects of temperature upon the toxicity of chemicals to aquatic organisms. - Hydrobiologia, 47, 135-171.

Dethlefesen, V. \& Westernhagen, H. von, 1983. Oxygen deficiency and effects on the bottom fauna of the eastern German Bight 1982. - Meeresforsch. 30, 42-53.

DHI, 1985. Uberwachung des Meeres, Bericht für das Jahr 1983. Teil II: Daten. Deutsches Hydrographisches Institut, Hamburg, $135 \mathrm{pp}$.

Gaul, H. \& Ziebarth, U., 1983. Method for the analysis of lipophilic compounds in water and results about the distribution of different organochlorine compounds in the North Sea. - Dt. hydrogr. Z. $36,191-212$.

Harms, U., 1976. Radiochemische Untersuchungen über den Abbau von Monomethylquecksilber mit Säure in Hinblick auf die Gesamt-Quecksilberbestimmung in Fischen. - Z. Lebensmittelunters. - Forsch. 162, 365-372.

Harms, U., 1981. Beiträge zur Spurenanalyse von Quecksilber im Nanogramm/Gramm-Bereich. - Z. Lebensmittelunters. -Forsch. 172, 118-122.

Holden, A. V. \& Topping, G., 1981. Report on further intercalibration analysis in ICES pollution monitoring and baseline studies. - Coop. Res. Rep. 108, 1-10.

ICES, 1979. Report of the ICES advisory committee on marine pollution, 1978. - Coop. Res. Rep. 84, 22-26.

ICES, 1984. The ICES coordinated monitoring programme for contaminants in fish and shellfish, 
1978 und 1979 and six-year review of ICES coordinated monitoring programme. - Coop. Res. Rep. 126, 1-100.

Jensen, A., 1982. Harmful substances in fish and shellfish. The Danish monitoring programme for 1979 and 1980 for the area covered by the Helsinki convention. - Rep. mar. Pollut. Lab. 1, 1-32.

JMG, 1985. Assessment of the results of the joint monitoring programme for 1983. Tenth meeting of the Joint Monitoring Group, Oslo 1985, JMG 10/14/1, \&3.8.

Köhler, A. \& Hölzel, F., 1980. Investigation on health conditions of flounder and smelt in the Elbe estuary. - Helgoländer Meeresunters. 33, 401-414.

Köhler, A, 1981, Fluktuationen der Fischfauna im Elbe-Ästuar als Indikator für ein gestörtes Ókosystem. - Helgoländer Meeresunters. 34, 263-285.

Kruse R. \& Krüger, K., 1984. Untersuchungen von Nordseefischen auf Gehalte an toxischen Schwermetallen und chlorierten Kohlenwasserstoffen im Hinblick auf lebensmittelrechtliche Bestimmungen. - Arch. Lebensmittelhyg. 35, 128-131.

Lienert, G. A., 1978. Verteilungsfreie Methoden der Biostatistik. Hain, Meisenheim am Glan, 2, $1-1246$.

Luckas, B., Pscheidl, H. \& Haberland, D., 1978. Determination of chlorinated pesticides and polychlorinated biphenyls by derivatization gas chromatography. - J. Chromat. 147, 41-46.

Luckas, B. \& Harms, U., 1986. Characteristic levels of chlorinated hydrocarbons and trace metals in fish from coastal waters and North and Baltic Sea. - Int. J, environ. anal. Chem. (in press).

Niimi, A. J., 1983. Physiological effects of contaminant dynamics on fish. Aquatic Toxicology. Ed. by Jerome O. Nriagu. Elsevier Science Publ., Amsterdam, 207-246.

Phillips, D. J. H., 1980. Quantitative aquatic biological indicators. Applied Science Publ., London, 197.

Schmidt, D., Freimann, P. \& Zehle, H., 1986. Changes in trace metal levels in the coastal zone of the German Bight. - Rapp. P.-v. Réun. Cons. int. Explor. Mer. 186 (in press).

Schulte, E. \& Malisch, R., 1983. Berechnung der wahren PCB-Gehalte in Umweltproben. I. Ermittlung der Zusammensetzung zweier technischer PCB-Gemische. - Z. analyt. Chem. 314, 545-551.

Sokal, R. R. \& Rohlf, F. J., 1969. Biometry, Freeman, San Francisco, 776 pp.

Specht, W. \& Tillkes, M., 1980. Gas-Chromatographische Bestimmung von Rückständen in Pflanzenbehandlungsmitteln nach Clean-up über Gel-Chromatographie und Mini-Kieselgel-SäulenChromatographie, - Z. analyt. Chem. 301, 300-307.

Thier, H.-P. \& Stijve, T., 1986. Ergebnisse eines Ringversuches zur Rückstandsanalyse von Organochlor- und Organophosphor-Pestiziden in Fett. - Lebensmittelchem. gerichtl. Chem. 40, $73-75$. 